\title{
Molecular and Biochemical Effect of Neem Extract On Experimental Diabetes
}

\author{
Omnia. M. Abdel Hamid \\ Biochemistry Department- Faculty of Vetrenary Medicine - Benha University
}

\begin{abstract}
Return to nature is now adays target of view so the aim of this study to evaluate aqueous extract effects of Neem leaf on streptozotocin (STZ) experimental diabetic rats. Sixty male rats were divided equally into 4 groups. first group used as healthy normal control, second group injected with $S T Z(50 \mathrm{mg} / \mathrm{kg} . \mathrm{B} . \mathrm{W})$ and act as control diabetic, third group injected I/P with STZ for induction of diabetes and treated with Neem leaf extract (200 mg/kg.B.W orally / day) for 30 days and the fourth group administrated with Neem leaf extract for 15 days before induction of diabetes, then during and after injection of STZ . for 30 days Blood samples were collected at $15 \& 30$ days from onset of treatment. Serum was directed for estimation of glucose, lipid profile, insulin hormone, insulin receptor, HMG-coA reductase, cortisol and total IgE. Hepatic tissue subjected to PCR for stimulation insulin receptors. The recorded results revealed significant increase in glucose, cholesterol, TG, insulin and HMGcoA reductase in diabetic rats when compared to control . The treatment with Neem extract resulted in significant decrease in all these parameters whereas serum cortisol has non significant change in all groups, while HDL showed non change in diabetic. In conclusion Neem act as potent antidiabetic, antihyperlipidemic and has a good molecular activity on insulin receptor gene expression by $P C R$
\end{abstract}

Key words: diabetes, Neem, hormone, lipid profile and PCR for insulin receptors

\section{Introduction}

Medicinal plant plays an important role in management of diabetes especially in developing countries. The WHO has defined herbal medicine as finished labeled medicinal products that contain active ingredients as aerial or underground parts of plants or other plant material (Romila et al., 2010). Many minor components of foods such as secondary plant metabolites have been shown to alter biological processes which may reduce the risk of chronic disease in human (Chattopadhyay and Bondyopadhyay, 2005).

Neem, belongs to family Meliaceae. Which is one of the most useful medicinal plants (Kausik and Ranajet 2002). The blood sugar level lowering activity of Neem oil and leaf extracts has been reported in various models of diabetic animal (Mostofa et al., 2007).

Different parts of Neem have been reported to have antiseptic, wound healing and skin disease curing activity (Biswas et al., 2002). Studies reveal that, leaves water extract of Neem possess significant antinflammatory, antiserotonin, antifertility and hepatoprotective activities (Chattopadhyay et al., 1993).

Diabetes mellitus is a metabolic disorder in the endocrine system. This dreadful disease is found in all parts of the world and becoming a serious threat to man kind health. There are lots of chemical agents available to control and treat diabetic patient, but nowadays several medicinal plants have been investigated for their beneficial use in diabetes. The effect of these plants may delay the development of diabetic complications and correct the metabolic abnormalities. Many phyto constituents responsible for antidiabetic effects have been isolated from hypoglycemic plants (Ultara et al., 2011). Therefore, the aim of this research is to measure the beneficial effects of using Neem leaves decoction as a natural herb on some blood parameters and insulin receptors on experimentally-diabetic rats

\section{Materials and methods}

Sixty male albino rats $12-16$ weeks old weighted $150-200$ gm were used in these experiments. Rats were kept at constant environmental and nutritional conditions throughout the experimental period. Water and feed were supplied ad-libitum.

\section{Induction of diabetes:}

Diabetes was induced by I/P injection of STZ at a dose of $50 \mathrm{mg} / \mathrm{kg} / \mathrm{b} . \mathrm{w}$ which dissolved in citrate buffer at pH 4.2 according to Ramanthan et al., (1999). A rise in blood glucose level was determined after 48 hr from injection of STZ

Preparation of Neem leaves extract:

Freshly prepared Neem leaves at a dose $(200 \mathrm{mg} / \mathrm{kg} / \mathrm{b} . \mathrm{w})$ extract were obtained by decoction.

Animal grouping:

Animals were divided randomly into 4 groups (15 each). Animals placed in a separate cage: 
Control group: injected only with citrate buffer.

Diabetic control: un-treated diabetic rats.

Neem treated group: diabetic rats treated with Neem leaves extract at a dose of $200 \mathrm{mg} / \mathrm{kg} / \mathrm{b}$.w/day orally for 4 weeks (Halim, 2003).

Protective group: rats administrated Neem leaves extract before induction of diabetes by 2 weeks as well as during and post induction of diabetes $/ 4$ weeks.

\section{Sampling:}

Blood samples were collected from all animals twice after 2 and 4 weeks from induction of diabetes. While the protected group collected another sample just before induction of diabetes. Samples were collected after overnight fasting from medial canthus of the eyes. Blood samples were centrifuged at 3000 r.p.m for serum separation which collected in clean tubes and directed for estimation of glucose (Trinder, 1969), total cholesterol (Frings and Dunn., 1970) triacyleglycerol (Bucolo and David., 1973), high density lipoprotein (HDL) (Finley et al., 1978), and hydroxymethylegtutryle CoA reductase (HMG-CoA) (Cighetti et al., 1988). Liver tissue were collected after 4 weeks and kept directly at $-80^{\circ} \mathrm{C}$ to to be used for insulin receptor expression evaluation (Schmittgen and Livak., 2008).

\section{ELISA technique}

ELISA was used for estimation of cortisol (Burtis 1994), IgE (Ishizaka, 1982), insulin hormone (Frosig 2007) and Insulin receptors (Cloud, 2013)

\section{PCR}

Total cellular RNA was extracted from tissue using a RNeasy Mini kit (Qiagen, Valencia, CA, USA) according to manufacturer's protocol. Real-time PCR was done using QuantiTect ${ }^{\circledR}$ SYBR $^{\circledR}$ Green RT-PCR kit (Qiagen, Valencia, CA, USA) according to the manufacture's protocol.

The real-time PCR cycling program consisted of reverse transcription at $48^{\circ} \mathrm{C}$ for $30 \mathrm{~min}$, initial PCR activation step at $95^{\circ} \mathrm{C}$ for $10 \mathrm{~min}$, followed by 40 cycles of $95^{\circ} \mathrm{C}$ for $15 \mathrm{sec}, 60^{\circ} \mathrm{C}$ for $1 \mathrm{~min}$, and the dissociation curve was added to the protocol whenever necessary. The real-time PCR assay was done using a 7300 real-time PCR system (Applied Biosystems, Foster City, CA, USA).

The amount of change in gene expression was calculated from the obtained cycle threshold (CT) values provided from real-time PCR instrumentation using the $2^{-\Delta \Delta \mathrm{CT}}$ calculation, where $\Delta \mathrm{CT}$ indicates the $\mathrm{CT}$ changes in target gene in comparison with the reference (house-keeping) gene ( Livak and Schmittgen., 2001 and Schmittgen and Livak., 2008).

\section{Statistical analysis}

The obtained data were statistically analyzed and the significant difference between groups was evaluated by analysis of variance (ANOVA) using SPSS (Statistical Package for Social Science, 1999; ver.10). The significance among the samples was compared at $\leq 0.05$, and $T$ - test was applied according to (Snedecor and Cochran., 1982)

\section{Results}

Table (1): Effect of Neem leaves extract on serum level of glucose ( $\mathrm{mg} / \mathrm{dl})$, total cholesterol (mg/dl), triacyleglycerol (mg/dl), HDL-c (mg/dl) and HMGCOA reductase $(\mathrm{pg} / \mathrm{ml})$.on rats before induction of diabetes

\begin{tabular}{|l|l|l|l|l|l|}
\hline $\begin{array}{l}\text { Parameters } \\
\text { Groups }\end{array}$ & Glucose & Cholesterol & TG & HDL & HMGCOA \\
\hline Control & $95.7 \pm 2.7$ & $80.6 \pm 3.4$ & $41.8 \pm 6.3$ & $37.1 \pm 6.5$ & $223.8 \pm 25.3$ \\
\hline Protective & $73.0 \pm 2.6^{* *}$ & $81.4 \pm 8.8$ & $68.2 \pm 4.4^{* *}$ & $36.1 \pm 2.0$ & $175.8 \pm 16.6$ \\
\hline
\end{tabular}

Mean value \pm standard error.

Superscript with different letters in the same column showed significant difference while same letters showing non significant difference

Table (2): Effect of Neem leaves extract on serum level of cortisol (ng/ml), IgE (ng/ml), insulin ( $\mathrm{uIU} / \mathrm{ml})$, and insulin receptors $(\mathrm{ng} / \mathrm{ml})$ on rats before induction of diabetes by 15 days.

\begin{tabular}{|l|l|l|l|l|}
\hline $\begin{array}{l}\text { Parameters } \\
\text { Groups }\end{array}$ & Cortisol & IgE & Insulin & $\begin{array}{l}\text { Insulin } \\
\text { receptors }\end{array}$ \\
\hline Control & $1.5 \pm 0.33$ & $17.3 \pm 1.1$ & $12.4 \pm 0.8$ & $1.95 \pm 0.45$ \\
\hline Protective & $1.7 \pm 0.14$ & $6.7 \pm 0.18^{* *}$ & $12.5 \pm 1.2$ & $1.5 \pm 0.23$ \\
\hline
\end{tabular}

Mean value \pm standard error. 
Superscript with different letters in the same column showed significant difference while same letters showing non significant difference

Tables (1 and 2) revealed that, rats administrated Neem leaves extract for 15 days before induction of diabetes (protective group) showed a significant decrease in serum glucose and IgE level when compared with control rats, while TG level was significantly increased in protected group. Other parameters showed nonsignificant changes when compared with control.

Table (3): Effect of Neem leaves extract on serum level of glucose $(\mathrm{mg} / \mathrm{dl})$, total cholesterol(mg/dl), triacyleglycerol (mg/dl), HDL-c (mg/dl) and HMGCOA reductase (pg/ml).on STZ induced diabetes in rats.

\begin{tabular}{|l|l|l|l|l|l|}
\hline \multicolumn{5}{|c|}{ After 2 weeks } \\
\hline $\begin{array}{l}\text { Parameters } \\
\text { Groups }\end{array}$ & Glucose & TG & HDL-c & HMGCOA \\
\hline Control & $95.7 \pm 2.66^{\mathrm{c}}$ & $80.63 \pm 1.9^{\mathrm{c}}$ & $41.83 \pm 6.30^{\mathrm{c}}$ & $37.1 \pm 6.54^{\mathrm{b}}$ & $223.8 \pm 15.44^{\mathrm{b}}$ \\
\hline Control diabetic & $245.3 \pm 16.18^{\mathrm{a}}$ & $121.4 \pm 4.19^{\mathrm{a}}$ & $85.17 \pm 5.57^{\mathrm{a}}$ & $69.4 \pm 1.93^{\mathrm{a}}$ & $386.5 \pm 11.39^{\mathrm{a}}$ \\
\hline Neem treated & $129.9 \pm 2.15^{\mathrm{b}}$ & $112.2 \pm 6.32^{\mathrm{ab}}$ & $50.3 \pm 3.33^{\mathrm{cb}}$ & $41.07 \pm 3.12^{\mathrm{b}}$ & $150.4 \pm 3.44^{\mathrm{c}}$ \\
\hline protective & $96.6 \pm 7.07^{\mathrm{c}}$ & $101.1 \pm 5.55^{\mathrm{b}}$ & $55.6 \pm 2.23^{\mathrm{b}}$ & $55.7 \pm 2.9^{\mathrm{ab}}$ & $235.7 \pm 3.15^{\mathrm{b}}$ \\
\hline \multicolumn{7}{|c|}{ After 4 weeks $^{\mathrm{b}}$} \\
\hline control & $110.2 \pm 7.71^{\mathrm{b}}$ & $72.43 \pm 1.74^{\mathrm{c}}$ & $95.33 \pm 1.42^{\mathrm{b}}$ & $39.17 \pm 3.59^{\mathrm{b}}$ & $180.0 \pm 2.1^{\mathrm{a}}$ \\
\hline Control diabetic & $240.3 \pm 22.85^{\mathrm{a}}$ & $131.3 \pm 3.83^{\mathrm{a}}$ & $153.3 \pm 2.48^{\mathrm{a}}$ & $71.23 \pm 2.81^{\mathrm{a}}$ & $222.8 \pm 6.1^{\mathrm{b}}$ \\
\hline Neem treated & $95.8 \pm 4.35^{\mathrm{b}}$ & $101.5 \pm 4.08^{\mathrm{b}}$ & $76.76 \pm 4.82^{\mathrm{b}}$ & $42.4 \pm 1.5^{\mathrm{b}}$ & $203.0 \pm 7.2^{\mathrm{a}}$ \\
\hline Protective & $88.3 \pm 4.93^{\mathrm{b}}$ & $105.8 \pm 2.06^{\mathrm{b}}$ & $98.43 \pm 2.0^{\mathrm{b}}$ & $40.5 \pm 3.43^{\mathrm{b}}$ & $195.6 \pm 5.16^{\mathrm{a}}$ \\
\hline
\end{tabular}

Mean value \pm standard error.

Superscript with different letters in the same column showed significant difference while same letters showing non significant difference

Table (3) revealed significant increase the serum level of glucose, cholesterol, triacyleglycerol, HDL$\mathrm{C}$ and HMG-COA reductase in diabetic rats when compared with control group all over the experimental period. Administration of Neem leaves extract to diabetic rats induced a significant decrease in serum levels of these parameters when compared to diabetic non treated rats and return to normal levels.

Table (4): Effect of Neem leaves extract on serum level of cortisol (ng/ml), IgE (ng/ml), insulin (uIU/ml), and insulin receptors $(\mathrm{ng} / \mathrm{ml})$ on STZ induced diabetes in rats.

\begin{tabular}{|l|l|l|l|l|}
\hline \multicolumn{5}{|c|}{ After 2 weeks } \\
\hline $\begin{array}{l}\text { Parameters } \\
\text { Groups }\end{array}$ & Cortisol & IgE & Insulin & Insulin receptors \\
\hline Control & $1.5 \pm 0.3^{\mathrm{a}}$ & $7.33 \pm 1.1^{\mathrm{a}}$ & $12.37 \pm 0.84^{\mathrm{b}}$ & $1.9 \pm 0.43^{\mathrm{ab}}$ \\
\hline Control diabetic & $2.1 \pm 0.06^{\mathrm{a}}$ & $7.6 \pm 1.08^{\mathrm{a}}$ & $22.53 \pm 2.54^{\mathrm{a}}$ & $2.8 \pm 0.41^{\mathrm{a}}$ \\
\hline Neem treated & $1.07 \pm 0.7^{\mathrm{a}}$ & $6.6 \pm 1.30^{\mathrm{a}}$ & $13.77 \pm 0.89^{\mathrm{b}}$ & $1.77 \pm 0.05^{\mathrm{b}}$ \\
\hline Protective & $1.4 \pm 0.07^{\mathrm{a}}$ & $6.9 \pm 0.43^{\mathrm{a}}$ & $9.0 \pm 1.2^{\mathrm{b}}$ & $1.6 \pm 0.15^{\text {ab }}$ \\
\hline \multicolumn{5}{|c|}{$\mathbf{A f t e r}^{\mathbf{b}}$ weeks } \\
\hline Control & $1.0 \pm 0.03^{\mathrm{a}}$ & $7.0 \pm 1.5^{\mathrm{b}}$ & $20.6 \pm 1.59^{\mathrm{b}}$ & $2.0 \pm 0.26^{\mathrm{a}}$ \\
\hline Control diabetic & $1.4 \pm 0.03^{\mathrm{a}}$ & $10.7 \pm 3.83^{\mathrm{a}}$ & $29.73 \pm 2.84^{\mathrm{a}}$ & $2.2 \pm 0.44^{\mathrm{a}}$ \\
\hline Neem treated & $0.9 \pm 0.02^{\mathrm{a}}$ & $6.2 \pm 1.9^{\mathrm{b}}$ & $15.03 \pm 1.05^{\mathrm{c}}$ & $1.7 \pm 0.23^{\mathrm{a}}$ \\
\hline Protective & $0 . .87 \pm 0.02^{\mathrm{a}}$ & $6.1 \pm 2.06^{\mathrm{b}}$ & $21.67 \pm 0.92^{\mathrm{b}}$ & $1.5 \pm 0.20^{\mathrm{a}}$ \\
\hline
\end{tabular}

Mean value \pm standard error.

Superscript with different letters in the same column showed significant difference while same letters showing non significant difference

Table (4) diabetic rats showed non-significant increase of serum cortisol concentration when compared with control. Neem treatment to diabetic rats showed non-significant decrease all over the period of experiment. Moreover, diabetic and treated rats revealed non significant increase in serum total $\operatorname{IgE}$ level after 2 weeks. While after 4 weeks IgE level was significantly increased in diabetic rats. Administration of Neem leaves extract to diabetic rats resulted in a significant decrease in serum total $\operatorname{IgE}$.

Diabetic rats revealed a significant increase in serum insulin level after 2 and 4 weeks. Administration of Neem leaves extract revealed a significant decrease when compared to diabetic rats and return to normal level when compared to control group.

Diabetic rats showed non significant increase in serum insulin receptors when compared with control. While rats administrated with Neem revealed a significant decrease after 2 weeks when compared with diabetic rats.

Table (5): Effect of Neem leaves extract on liver insulin receptor by RT. PCR.

\begin{tabular}{|l|l|}
\hline Grouping & Insulin receptors(RT. PCR) \\
\hline
\end{tabular}


Biochemical Effect of Neem Extract On Experimental Diabetes Gene Expression

\begin{tabular}{|l|c|}
\hline Control & $1 \pm 0.03$ \\
\hline Control diabetic & $0.04 \pm 0.00^{\mathrm{a}}$ \\
\hline Neem group & $0,09 \pm 0.00$ \\
\hline Protective group & $0.08 \pm 0.00$ \\
\hline
\end{tabular}

Mean value \pm standard error.

Superscript with different letters in the same column showed significant difference while same letters showing non significant difference

Table (5): Similarly, expression of hepatic insulin receptor showed down-regulation in all groups when compared with control as detected by real-time PCR. Administration of Neem leaves as protected or treated groups reveal an initiation of gene expression when compared with diabetic control.

\section{Discussion}

Diabetes is a metabolic disease in which a person has high blood glucose either because the body does not produce enough insulin or the body cells do not respond to insulin that is produced (Kumar et al., 2011). Experimentally induced diabetic rats showed significant increase in serum glucose level which may be attributed to the body tissue don't respond very well to insulin signal and therefore don't metabolize the glucose in diabetic rats (Richard., 2007). Furthermore, Rosa et al., (2011) attributed the increase of blood glucose in STZ diabetic rats to the nitrosourea derivivates that has diabetogenic activity due to its ability to induce oxidative stress and damage to $\beta$-cells by producing free radicals of oxygen, nitrogen mono oxide and reducing intracellular NAD and NADP.

Pretreatment with Neem leaf prevented the rise in blood glucose levels as compared to control. These indicated that Neem could be beneficial in diabetes mellitus as controlling blood sugar or may also be helpful in delaying the onset of the diabetes due to its pharmacological activity. (Khosla et al., 2000).

Administration of Neem leaves extract to diabetic rats exhibit a significant decrease in serum level after 2 and 4 weeks these results came in accordance with (Boby et al., 2003) that proved Neem extract increase the peripheral utilization of glucose and decrease in insulin resistance. A possible mechanism is to inhibit action of epinephrine on glucose metabolism resulting in increase utilization of peripheral glucose (Chattopadhyay, 1996). Aqueous extract of Neem leaves significantly decrease blood sugar level and prevent adrenalin as well as glucose - induced hyperglycemia. When aqueous leaf extract fed orally it produce hypoglycemia in normal rats and blood glucose level in experimentally STZ induced diabetes in rats. These results are similar to the results of this study. ( Rao et al., 2012).

The recorded data revealed a significant increase in serum level of total cholesterol, triacyleglycerol, and HDL-c in diabetic rats these could be attributed to the link between diabetic dyslipidemia and insulin resistance which is the precursor of type 2 diabetes and these factors raises risk of heart attack and stroke (Richard, 2007). However, insulin activates enzyme lipoprotein lipase which hydrolyses triacyleglycerol under normal condition .destruction of beta cells lead to depletion of plasma insulin, which resulted in hyperlipidemia and hypercholestermia caused derangement of metabolic abnormalities (Rasineni et al., 2010) .Moreover, the elevated levels might be due to the stimulation of hepatic triacyleglyceride synthesis as a result of free fatty acid influx (Maghrani et al., 2004). A significant decrease in serum level of cholesterol, TG and HDL-c agreed with Kumar et al., (2010) who reported that, repeated administration of Neem has beneficial effect on hyperlipidemia associated with hypoglycemia. Furthermore, Chattopadhyay and Bandyopadhyay., (2005) demonstrated that, treatment with Neem leaves extract to diabetic rats revealed a significant decrease in total cholesterol and TG while return HDL to normal level these may be explained that, the chemical analysis of Neem leaf extract contain compounds including Quercetin -3-o-B-D-glucoside, Myricetin-3-rutinoside, Quercetin-3-o-rutinoside, Kaempferol-3-o-rutinoside, Kaempferol-3-O-B-D-glucoside, Quercetin-3-O-Lrhamnoside either wholly or partially may be responsible for antihyperlipidemic activity. In addition, it contains Nimbidin which significantly reduce serum cholesterol that helps to reduce blood clots. It also causes dilatation blood vessels and may be responsible for helping as hypotensive and improve blood circulation (Host. 2012).

Purohit, (1999) recorded that; Neem leaf extract feed to cholesterol fed rabbit resulted in reduction in serum total cholesterol, and HDL-c this indicated that Neem has antiatherogenic or hypolipidemic microconsistutent.

In this study the significant increase in HMGCoAreductase in diabetic rats agreed with (Magni et al.,1992) who exhibited that, the percentage of the active thiolic dephosphorylated form was higher in these diabetic animals than control suggesting a response of the liver to the decrease in both total and specific activity of HMGCoA reductase.

On other hand, rats administrated Neem leaf extract (protective group) showing significant decrease in serum HMGCoA reductase activity. These results are in harmony with Bopanna et al., (1997) who reported a significant decrease in the concentration of serum lipid, glucose and enzymes activity of ALP, LDH, G6P and HMGCoA reductase due to antidiabetic and antihyperlipidemic effect of Neem. 
This study investigated that, serum cortisol level showed non significant change in diabetic rat and treated group. These results agreed with Gholap and Kar (2004) suggested that, Neem could exhibit hypoglycemic activity without altering the serum cortisol concentration. This may be due to plant extracts may potentially regulate corticosteroid induced diabetes mellitus. Some chronic diseases as diabetes and cancer are associated with production of free radicals and advanced glycation end product (Jane, 2006).

A significant increase of serum insulin and non significant increase in insulin receptors in diabetic rats may be due to that, pancreas can still produce the insulin hormone eventually insulin production dwindles in type 2 diabetes (Ian, 2008). Furthermore, Colen (2013) recorded a new hormone called Betatrophin that will cause mice to produce insulin - secreting by beta cells up to 30 times than normal rate. The new beta cells only secret insulin which offering the potential for the natural regulation of insulin and great reduction in the complication associated with diabetes.

Krishnapuran et al., (2013) recorded that, insulin-resistant states in obesity or diabetes are often associated with a decrease in the binding of insulin to insulin receptors, and/or a decrease in insulin-stimulated activation of IRS, which may diminish the effectiveness of anti-diabetic agents dependent on this signaling.

Administration of Neem leaf extract demonstrated a significant decrease in serum insulin level and non significant decrease in serum insulin receptors. These results agreed with Joseph, (1999) who reported that, drinking a simple cup of tea out of leaves Neem extract significant and consistently reduced insulin requirements for nonkeytonic, insulin fast and insulin sensitive form of diabetes. furthermore, Klaus, (2007) indicated that, number of insulin - dependant diabetic were able to reduce their insulin considerably when treated with Neem leaf extract and Neem oil in which the general impression is that Neem may enhance insulin receptor sensitivity and may work well on type 2-diabetes. Next, we studied the biosynthesis of the insulin receptor. Real time PCR referred that insulin receptors were down regulated in diabetic patient when compared to control diabetic and treated group these results agreed with (William 1978) who recorded that, down regulation reduction in cellular receptor expression for specific hormone done when the concentration of that hormone is increased. Obesity and diabetes are associated with decrease expression of insulin receptor. An inverse relation ship between insulin concentration and insulin receptor number (Olefsky 1978). Furthermore, Khan et al., (1978) domenstrated that only pathogenic condition in which a decrease in insulin receptor has been definitialy shown to be result of insulin resistance and hyperinsulinism. Moreover, increased cortisol level might cause insulin receptor down-regulation (William 1978).

Administration of Neem to diabetic rats improved gene expression of insulin receptors when compared with control diabetic these results agreed with sharma (2013) who recorded that Neem enhance insulin receptor sensitivity, help in blood circulation by dialing blood vessels and decrease glucose level.

Diabetic rats showed a significant increase in the serum IgE level after 4 weeks. These results came in accordance with Madacysy et al., (1983) who reported that total $\operatorname{IgE}$ level higher than normal in diabetic children this may be due to existence of symptoms of free atrophy in IDDM that proved autoimmune pathogenesis of insulin-dependant diabetes. Moreover, a high level of $\operatorname{IgE}$ was found in diabetes, autoimmune disease, and arthritis .it was further revealed that people who have increase level of IgE showed increase myoglobin and insulin (Binie., 2009) .The mast cell activator immunoglobulin IgE may serve as a novel inflammatory that associate with the risk of pre-diabetes and diabetes mellitus (Wang.,2011).

Neem extract administration revealed decrease in $\operatorname{IgE}$ level this may be attributed to presence of nimbidin which one of Neem leaves consistituent that has potent diuretic and anti-inflammatory properties (Mitra et al., 1978). In addition Neem leaf and its consistituents have been demonstrated to exhibit immunomodulatory, anti-inflammatory and antioxidant properties (Subapriya and Nagini; 2005). From this study we recommended with treating diabetes mellitus with plant derived compounds as Neem which are accessible and do not require laborious pharmaceutical synthesis and has no side effects.

\section{References}

[1]. Binie Ver Lipps (2009): Immunoglobulin E (IgE) novel treatment for lowering the concentration of IgE. Rose dog. Books page 90.

[2]. Biswas Kausik, Chattopadhyay Ishita, Banerjee Ranjit and Bandyopadhyay Uday (2002): Biological activities and medicinal properties of neem (Azadirachta indica) Current Science, 82(11), 1336-1345.

[3]. Boby RG and Leelamma S (2003): Mechanism of hypoglycemic action. Plant Foods Hum Nutr. 58: 7-13

[4]. Bopanna, K.N.et al 1997: Indian .J. Pharmacol., 29(3), 162.

[5]. Bucolo, G and David, H. (1973): Quentitative determination of serum triglycerides by use of enzymes. Clin. Chem. 19, 475-482.

[6]. Burtis CA and Ashwood ER(1994): Tietz textbook of clinical chemistry. $2^{\text {nd }}$ ed.philadephia.

[7]. Chattopadhyay R(1993): Effect of Azadirachta indica leaf extract on oestrous cycle of ratsa . Environment and Ecology, 11(4), 958-960.

[8]. Chattopadhyay RR(1996): Possible mechanism of antihyperglycemic effect of Azadirachta indica leaf extract, part IV. Gen. Pharmacol., 27:431-434.

[9]. Chattopadhyay RR. And Bandyopadyay M (2005): Possible mechanism of hepatoprotective activity of leaf extract against paracetamol-induced hepatic damage in rats. Indian. J. Pharmacol. 37: 184-5.

[10]. Cighetti G, Del Puppo M, Paroni R and Galli Kienle M (1988): Modulation of HMGCOAreductase activity by pantetheine/pantethine. Biochim Biophys. Acta 963: 389-393. 
[11]. Cloud Clone Corp(2013): enzyme -linked Immunosorbent Assay for Insulin receptor. $10^{\text {th }}$ Edition

[12]. Colen (2013): Potential diabetes breaks through. Science and health 25(4)

[13]. E. Magni, M.Cancellieri, M. Ded Puppo and M. Galli Kienle (1992): Diabetes -induced alteration of HMGCOA reductase forms in rat livers. Diabetologia.

[14]. Finely, P.R, Schifmou, K.B, Williams, R.J and Lichti, D.A (1978): Cholesterol in high density lipoproteins: use of $\mathrm{Mg}^{2}+\operatorname{destran}$ sulfate in its enzymatic measurement. Clin. Chem. 24, 931-933.

[15]. Frings, C.S and Dunn, R.J(1970): Calorimetric method for determination of total lipids based on the sulfophospho-vanillin reaction. Amer. J. Clin. Path. 53, 89-91.

[16]. Frosing, C, Rose. A.J, Treebak, T, Kiens, B, Richter, E.A and Wojtaszewski, J.F.P (2007): Effects of endurance exercise training ob insulin signaling in human skeletal muscle: interaction at the level of phosphatidylinositol 3-kinase, Akt, and AS160. Diabetes 56: 2093-2102.

[17]. Gholap S and Kar, A (2004): Hypoglycemic effects of some plant extracts are possibly mediated through inhibition in corticosteroid concentration. Pharm. 59: 876-878.

[18]. Dine host (2012): neem leaf. Herbal Extracts Plus .http://www.herbalextractsplus.com/neem-leaf.htm/

[19]. Halim E.M (2003): Lowering of blood sugar by water extract of Azadirachta indica and Abroma augusta in diabetes rats. National Chemical Labolatory. Pune 411008, India.pres@ems.ncl.res.in

[20]. Ian Campbell (2008): Type 2 diabetes . Net doctor Based on a text by De Jan Erik Henrikson.

[21]. Ishizaka T(1982): An allergy, 48:313.

[22]. Jane Dixon(2006): exhaustion phase.biology of Kundalini. http://biologyofKundalini.com.article.php?story=exhaustionphase.

[23]. Joseph Selvester(1999): Neem " The Village Pharmacy".Ayurvedic Practitioner and Master Herbalist.

[24]. Kausik BL,and Ranajet KB (2002): biological activities and medicinal plant properties of neem plant. Curr Sci. 82:1336-45.

[25]. Khan, C.R.,Flier, J.S and Bar, R.S (1976): The syndrome of insulin resistance and Acanthosis Nigrican. N. Engl. J. Med. $294: 739$

[26]. Khosla, P (2 000): Indian Journal of Physiology and Pharmacology, 44(1), 69.

[27]. Klaus Ferlow (2007): The Miraculous Neem.

[28]. Kumar PM, Sasmal D and Mazumder PM (2010): The antihyperglycemic effect of aerial parts of Saliva splendens (scarlet sage) in streptozotocin - induced diabetic -rats. Pharmacogen Res. 3: 190-4.

[29]. Livak, K.J and Schmittgen, T.D (2001): Analysis of relative gene expression data using real-time quantitative PCR and the 2 (Delta delta C(T) Method. Methods (Scan Diego, Calif) 25 (4), 402-408

[30]. Madacsy L, Feher A and Kassay L (1987): High IgE levels in diabetic children without atopy or insulin allergy. Acta. Paediatr. Hung: 28(3-4):209-13.

[31]. Maghrani M, Zeggwagh NA and Lemhadri A(2004): Study of the hyperglycemic activity of Fraxinus excelsior and Silybum marianum in an animal model of type 2 diabetes mellitus. J Ethnopharmacol. 91: 309-16.

[32]. Mitra and Riechst Aromen (1978): information from Dr,C.R. Mitra, NBRI, Lucknow.28, 44.

[33]. Mostofa M. Chouhury ME, Hossain MA and IslamIslam MH (2007): Antidiabetic effects of Catharanthus roseus, Azadirachta indica, Allium Sativum and glimepride in experimentally diabetic rat. Bangladesh J Vet Med. 5:99-102.

[34]. N.K Sharma (2013): Diabetes mellitus and its herbal treatment. Home remedies for diabetes. July 3

[35]. Olefsky, J.M (1976): The insulin receptor: Its role in insulin resistance of obesity and diabetes. Diabetes 25: 1154.

[36]. Purohit, A(1999): Drugs, 36(6), 389.

[37]. Ramanthan, M; Kaiswal, A.K. and Bhattathacharya, Y.S.K (1999): Superoxide dismutase, catalase and glutathione peroxidase activity in the brain of STZ induced diabetes in rats. Indian J. Exp. Biol., 37: 182-183

[38]. Rao, A.V, Madhuri, V.R.S, and Prassad, Y.R (2012): Evaluation of the in vivo hypoglycemic effect of neem (Azadirachta indica A. Juss). Fruit, aquous extract in normoglycemic rabbit. Research Journal of Pharmaceutical, Biological and Chemical Science 3:799-806.

[39]. R Krishnapuram, H Kirk-Ballard, E J Dhurandhar, O Dubuisson, V Messier, R Rabasa-Lhoret, V Hegde, S Aggarwal and N V Dhurandhar (2013): Insulin receptor- independent up regulation of cellular glucose uptake. International journal Of Obesity 37, 146-153

[40]. Rasineni K, Bellamkonda R, Reddy SS and Desireddy S(2010): Antihyperglycemic activity of Catharanthus roseus leaf powder in streptozotocin - induced diabetic rats. Pharmacogen Res. 3: 195-200.

[41]. Richard, N.M.(2007): Diabetes and cholesterol- American. Assoc. Jul. 16.

[42]. Romila YP, B. Mazumder and M. Dutta Choudhury (2010): A review on antidiabetic plants used by the people of manipur characterized by hypoglycemic activity. Biological and Environment Science. 6(1): 167-175.

[43]. Rosa Martha Perez Gutierrez, Yolanda Gomez Y, Gomez and Monica Damian Guzman (2011): Attenuation of nonenzymatic glycation, hyperglycemia, and hyperlipidemia in streptozotocin -induced diabetic rats by chloroform leaf extract of Azadirachta indica. Pharmacogen Mag. 7(27): 254-259.

[44]. Schmittgen, T.D and Livak, K.J (200): Analyzing real - time PCR data by comparative C(T) method. Nature Protocols 3 (6), 1101-1108.

[45]. Snedecor, G.W and Cochran W.G(1992): Statistical methods $6^{\text {th }}$ ed. The Iowa state Univ. Press. Anes. Iowa, USA.

[46]. Subapriya, R and Nagini, S (2005): Medicinal properties of neem. A. review. Curr. Med. Chem. Anticancer agents . Maer5(2): 149-6.

[47]. Trinder, P. (1969): An Clin. Biochem, 6-24.

[48]. Uttara Singh, Anita Kochhar and Sadhana Singh (2011): Blood glucose lowering potential of some herbal plants.Journal of Medicinal Plants Research Vol. 5(19), pp. 4691-4695.

[49]. Wang Z, Zhang H, Shen XH, Jin KL, Qian L, Li B, Zhang YH and Shi GP (2011):Immunoglobulin E and mast cell proteases are potential risk factors of human pre-diabetes and diabetus mellitus. PLoS One. 6(12).

[50]. William G. Blackard, M.D; Philip, S, Guzelian, M.D and Esther, E. Small (1978): Down regulation of insulin receptors. American Clinical and Climatological Association. October (24). 